\title{
Performance of traditionally-managed Bunaji (White Fulani) cattle under smallholder dairy production systems in Oyo State, South-West, Nigeria
}

\section{O. A. Olafadehan*, ${ }^{*}$, M. K. Adewumi ${ }^{2}$ and A. A. Busari ${ }^{3}$}

${ }^{1}$ Department of Animal Science, University of Abuja, Abuja, Nigeria

${ }^{2}$ Department of Animal Science, University of Ibadan, Ibadan, Nigeria

${ }^{3}$ International Livestock Research Institute (ILRI) P. M. B. 5320, Ibadan, Nigeria

Running head: Performance of traditionally-managed cattle in south-western Nigeria

Corresponding author: oaolafadehan@yahoo.com

\section{Abstract}

The remarkable reduction in tsetse fly and its vector trypanosomosis in the South-West zone of Nigeria have led to the development of smallholder dairy production which is predominantly practised by the Fulani agropastoralists in the zone. This study was conducted by the administration of structured questionnaires to farmers in the Derived savannah area of Oyo State in the South-West zone of Nigeria with aim of assessing the performance of traditionally managed Bunaji (White Fulani) cattle in this newly encroached zone by the Fulani pastoralists from the northern parts of the country. The survey showed that milk offtake or partial milk yield $(0.6 \mathrm{~kg} /$ day), pregnancy rate $(53.2 \%)$, calving rate $(49.5 \%)$, calf crop (37.11\%) and body condition score (4.3) were low and typical of tropical breeds of cattle. Also, average age at first calving (47.8 months) and calving interval (18.1 months) were on the high side. Majority (80\%) of the dams produced their young ones during the wet season while a few ones (20\%) calved during the dry season. Diarrhoea (84\%), helminthosis (72\%) and sand eating (64\%) were the major diseases of calves in wet and dry season, respectively; whereas in addition to diarrhoea and sand eating, low milk production $(90 \%)$ was peculiar to adult cattle in dry season. Calves' overall mortality was $24.11 \%$ with majority (73.77\%) occurring during the first week of life; it was higher in wet season $(86.89 \%)$ compared to the dry seas on $(13.11 \%)$. Overall mortality for adult cat tle was $5.83 \%$ with the mortality, in contrast to the calves' mortality, being higher in dry season (69.39\%) than in wet season (30.61\%), and the females (91.84\%) more susceptible than the males $(8.16 \%)$. The results indicate that the performance of traditionally-managed cattle in smallholder dairy production systems in Oyo State, South-West, Nigeria is poor and below their genetic potentials due to poor management.

Keywords: Major diseases, mortality, milk offtake, reproductive performance, seas on

\section{Introduction}

Livestock production is a source of employment and livelihood among many Nigerians. Of all the livestock species, cattle are very prominent and are the most predominantly and highly valued livestock in Nigeria. This is evident by the fact that cattle meat (beef) is the most popular type of meat consumed by Nigerians.

Majority of cattle reared in Nigeria are found in the northern parts of the country due low incidence of diseases, particularly trypanosomosis transmitted by tsetse flies. However, in spite of the suitability of these areas for the production of cattle, production is usually constrained by the problem of scarcity of forages in the dry season which lasts for 5-7 months in the Sudano-sahelian zone of the northern Nigeria, which hosts most of the cattle. Because of this problem, the Fulani 
pastoralists who are reputed to own substantial percentage of the national herds (Olafadehan and Adewumi, 2007) do engage in migratory system into the southern parts of the country, which have been considered unfavourable to cattle production due to trypanosomosis challenge. However, in recent times, cattle production, which was once beset by trypanosomosis in the South-West of Nigeria, is now becoming prominent due to the influx and settlement of the pastoralists, who have been displaced from their ecological zone in the northern areas of the country by a variety of agro-ecological and socio-economic factors to the South-West zone where there is abundance of pastures for most part of the year for their stock (Iyayi et al., 2003). According to Mohammed (1990), the resettled cattle pastoralists have abandoned their traditional migratory transhumant system and replaced it with a sedentary system in which cattle husbandry is combined with crop cultivation. Under this system, the cattle and the agropastoralists are permanently settled and do not engage, wholly or partly, in any regular pattern of transhumance except those dictated by natural disasters such as outbreaks of human and livestock diseases.

There is, nevertheless, paucity of information on the performance of these traditionally managed cattle in the newly or recently occupied areas, the South-West zone of Nigeria. It is against this background that this preliminary study was conducted to generate information and as well as assess the performance of the Bunaji cattle in the South-West of Nigeria.

\section{Materials and Methods Description of the study area}

The study was conducted on-farm among the agropastoralists settled in the Atiba and
Oyo West Local Governments in Derived savannah area of Oyo State, south-western Nigeria. It lies roughly between longitude $3^{\circ}$ $4^{\prime}$ West, $6^{\circ} 4^{\prime}$ East of Greenwich and latitude $6^{0} 10^{\prime}$ and $9^{\circ} 10^{\prime}$ North of the equator. The study area is bounded in the north by the southern Guinea savannah zone and in the south by the interface between the lowland rain forest and southern parts of the Derived savannah. Annual rainfall is between 1,500 and $2,000 \mathrm{~mm}$ and follows a bimodal distribution. The temperature ranges from $22-33^{\circ} \mathrm{C}$ while the wet season lasts for 8.0 8.5 months starting from mid-March to mid-November.

Sampling procedure

Based on adaptable previous surveys and past classifications of cattle agropastoralists conducted in the study area, which identified 60 agropastoralists, by the International Livestock Research Institute (ILRI), 50 agropastoralists were used for the study.

Data collection and analysis

Data were collected for six months using observations and a combination of informal and formal surveys with the household heads. Thus, primary data were collected by the administration of both open-ended and close-ended structured pre-tested questionnaires to the sampled agropastoralists. The administered questionnaires broadly centered on reproductive performance, milk offtake (partial milk yield or extractable milk for human consumption) and mortality of the animals. The interviews were conducted in the early hours of the day before the pastoralists left the homestead otherwise called "ruga" with the animals for grazing. Milk offtake was estimated by using measuring cylinder to measure the milk extracted from 40 cows for 3 months lactation period. Measurement commenced a week after calving to allow calves access 
to the colostrums and milk extraction was once a day and invariably in the morning. The calves were used to initiate milk letdown. Body condition score was estimated according to the method described by Nicholson and Butterworth (1986). Pregnancy rate, calving rate and calf crop were estimated as indicated below.

Pregnancy rate $=$ Number of pregnant animals in a year/ Number of breeding cows in the herd $\mathrm{x} 100$

Calving rate $=$ Number of calves produced in a year/ Number of breeding cows in the herd $\mathrm{x} 100$

Calf crop $=$ Number of calves weaned in a year/ Number of breeding cows in the herd $\mathrm{x} 100$

Descriptive statistics were computed using the Statistical Package for Social Scientists (SPSS) 11.0 for Windows (2001).

\section{Results and Discussion}

The reproductive performance of cattle in smallholder dairy production systems in the agropastoral farming system in the SouthWest, Nigeria is shown in Table 1. The average milk offtake value of 0.60 $\mathrm{kg} / \mathrm{cow} /$ day compares favourably with offtake values of $0.42-0.62$ and 0.71 $\mathrm{kg} /$ cow/day reported by Otchere (1986a) and Nasiru et al. (2009), respectively, for Bunaji cows under similar conditions in the northern parts of the country. Similarly, Okantah (1992) and Karbo et al. (1998) reported daily milk offtake of about 0.9 and $0.7 \mathrm{~kg}$ in wet and dry season, on Accra Plains and northern Ghana, respectively, for traditional managed herds in smallholder dairy production systems. From the foregoing, it had been generally agreed that the indigenous cattle kept by smallholders are low milk producers. It should, however, be pointed out that milk offtake figures of $0.42-0.90 \mathrm{~kg} / \mathrm{cow} /$ day did not represent the genetic potential of the animals used in those studies because (1) the amounts did not include milk consumed by the calves, (2) the cattle had not been selected for high milk yield nor (3) the environment improved enough to really enable animals to demonstrate their full genetic make-up for high milk yield. It is pertinent to mention that the Fulani pastoralists depend on the sales of the extractable milk for human consumption to augment their income, while consumption by family members of smallholders improved the nutritional status of family members. Whereas the average age at first calving is similar to 46.8 months reported by Barje et al. (1995), it was lower than the values of 60 and 50.2 months indicated by Pullan (1980) and Otchere (1986b), and Wagenaar et al. (1986) and Mukasa-Mugerwa (1989), respectively, for grazing Bunaji cows. When judged by their temperate counterparts, the average age at first calving is high. Generally, cattle breeds indigenous to the tropics have been known to have low reproductive efficiency when compared to their temperate counterparts principally due to poor nutrition, health management and genetic quality because the animals have not been carefully selected and bred for improvement over the years. The average lactation length is lower than the lactation length of 11 and $10.1-14.0$ months reported by Wagenaar et al. (1986) for pastoral Sudanese Fulani in Mali and free grazing Bunaji cows in Nigeria (Barje et al., 1995), respectively. The difference in the lactation length could be due to variations in the milking methods, intensity of milking and frequency of milking. For cattle reared under traditional management systems, lactation length is usually high since farmers depend on the extracted milk 
Table 1: Reproductive performance of Bunaji cattle in the agropastoral system

\begin{tabular}{lll}
\hline Reproductive indices & Total number of cattle & Result \\
\hline Milk offtake (kg/day) & 40 & $0.60 \pm 0.10$ \\
Lactation length (month) & 430 & $8.30 \pm 5.30$ \\
Pregnancy rate (\%) & 512 & 53.3 \\
Calving rate (\%) & 512 & 49.5 \\
Calving interval (month) & 380 & $18.1 \pm 10.25$ \\
Age at first calving (month) & 405 & $47.8 \pm 19.58$ \\
Weaned calf crop (\%) & 512 & 37.1 \\
Body condition score & 40 & $4.3 \pm 0.51$ \\
Season of calving & Frequency & $\%$ of farmers \\
Wet season & 40 & 80 \\
Dry season & 10 & 20 \\
\hline
\end{tabular}

from the animals for livelihood; therefore animals are milked until the calves, which are used to initiate milk let-down, are naturally weaned or the cow dries off, whichever comes first. The estimated pregnancy rate $(53.3 \%)$, one of indices for fertility rates of a cattle herd, and the calving rate $(49.5 \%)$ were similar to each other. These results simply suggest that detectable premature births (stillbirths) and/or advanced embryonic losses were very minimal. The calving rate is, however, low and typical of tropical breeds of cattle raised under traditional management conditions. Parallel studies revealed the low fertility of zebu cattle in tropical and subtropical areas (Fitzpatrick, 1993). The calving rate is similar to the rate of $46.0 \%$ reported by Okoruwa et al. (1999) for traditionally managed Bunaji cattle, but lower than the rates of $57 \%$ in Kenya and $54 \%$ in Mali (De Leeuw and Thorpe, 1995). The average calving interval is within the range of 16.1 - 25 months indicated by Mukasa-Murgewa (1989) for Nigerian indigenous cattle, but lower than the calving intervals of 25.2 and 27 months reported by Otchere (1986b) and Pullan (1979), respectively. In general, the calving interval of grazing cows in traditional systems of management is high obviously due to poor nutrition, prolonged postpartum anoestrous, which invariably results in delay in resumption of ovarian activities and consequently ovulation and heat, principally due to prolonged or extended milking periods and lactation stress or suckling, dam old age and high ratios of cows to breeding bulls. There is evidence that tropical cattle breeds have prolonged periods of postpartum anoestrous leading to long calving to service interval (Galina and Arthur, 1989). It has been established that extended or intense suckling or milking leads to anoestrous condition in cows and hence longer calving intervals (Olafadehan, 2007). Generally, fertility of cows kept under traditional extensive systems has been shown to be low as indicated by long postpartum anoestrous period and long days to conception in the majority of cows investigated (Elmansoury et al., 2002). Therefore, whereas frequent calvings (and hence opportunity to milk) are crucial in smallholder market oriented dairy systems, as practised in traditional systems, and cows need to be sucked by calves before milking can occur, factors which tend to disrupt the return to oestrus and establishment of pregnancy, e.g. suckling and milk extraction will need to be counterbalanced by other practices as feed supplementation. Estimated calf crop showed that only $37 \%$ of the breeding cows 
in the herd were capable of nursing a calf to weaning age. This value was low probably due to poor management systems which exposed the calf to inclement weather, poor nutrition and health, and consequently high mortality. The mean body condition score is fairly okay but fell below the threshold body condition of 5.0 in the scale of 9 recommended for optimal reproductive performance (Nicholson and Butterworth, 1986). This low figure is a reflection of the plane of the nutrition of the animals which dictates conception rate and calving interval. Perhaps this probably explains the reason for the poor performance of indigenous cattle since fertility/conception has been reported to be positively correlated with condition scores (Nicholson and Butterworth, 1986; Okantah et al., 1999; Lents et al., 2008). Nicholson and Butterworth (1986) noted that to attain high pregnancy rates, a breeding cow must manage for a $5+$ to 6 scores to insure sufficient fatness for reproductive fitness and as condition falls below a 5, so will pregnancy rates and calving intervals. Okantah et al. (1999) reported that feed supplementation during dry season reduced calving interval, with $53.8 \%$ of supplemented cows resuming ovarian activity within the first 60 days while none of the non-supplemented cows cycled earlier than 60 days. Whereas Olafadehan and Adewumi (2009) reported a reduction of $24-54$ days in the calving intervals of prepartum supplemented free grazing Bunaji cows, Okantah et al. (1999) observed a much higher reduction of 18 24 months as a result of simple supplementation of traditionally-managed cows in a smallholder dairy production system. Indeed, nutrition has been recognized as having a major effect on the length of postpartum anoestrous period in dairy and beef cows; factors such as inadequate nutrition (limited dietary energy and protein intake) have been reported to delay postpartum resumption of ovarian cyclicity in cattle (Lucy, 2003; Burke and Roche, 2007). Thus, the general belief that tropical cattle, particularly Zebu, have low fertility may be due to poor or inadequate nutritional environment rather than genetic inadequacy. The higher calving in the early wet season suggests that the dams that calved were serviced toward the second half of the wet season of the previous year when pastures were abundantly available. Zakari et al. (1981) observed few oestrous cycle in Bunaji cows during the dry and prerainy seasons when behavioural signs of heat were poorly manifested and lasted for a short period unlike during the rainy season when the duration of oestrous and behavioural signs of heat were much pronounced. The result indicates that breeding is largely controlled via the seasonal variations in quality and quantity of available pastures. The aforementioned reasons coupled with the report of Butterworth (1983) which indicated high correlations between rainfall and calving tend to justify the predominant calving in wet season. The result agrees with previous observations in Sudan (Elmansoury et al., 2002).

Presented in Table 2 are the prevalent diseases affecting adult cattle and calf in the agropastoral system in the study area. Among the calves, diarrhoea $(84 \%)$ and worm infestations (helminthosis) (72\%) were the major diseases during the wet season. The conducive prevailing environmental conditions during the wet season could be responsible for this. These findings are corroborated by other studies (Alawa et al., 2001; Taiwo et al., 2007), where helminthosis and gastro-enteritis were highlighted as major health problems prevalent in cattle reared in peri-urban and 
urban areas, respectively. Sand eating, otherwise known as geophagy, was peculiar to both adult and young cattle in dry season. Sand eating could be due to poor nutrition especially mineral imbalance or deficiency. Inadequacy of phosphorus and cobalt is known to result in pica, a disease condition in which animals, particularly cattle, eat virtually everything. This could further be buttressed by lower cases of sand eating (44\%) reported in wet season when pastures are copiously available as against (90\%) indicated in dry season for adult cattle. Olanite et al. (2003) had earlier reported sand eating as one of the major diseases of traditionally-managed calves in sub-humid area of Nigeria. Low milk production of the lactating dams was also indicted as another major health problem affecting the productivity of the traditionally-managed Bunaji cattle. Virtually all the respondents attributed this problem to poor quantity and quality of tropical forages on the open range grazed by the animals. From the foregoing, it seems that poor nutrition rather than health problem is the major limiting factor affecting the performance of the grazing cattle in the South-West of Nigeria.
Table 3 shows the seasonal calf mortality in the study area. There were indications that the incidence of stillbirth was very low. This implies that that majority of the pregnant cows gave birth to their young ones alive. This is comparable to the stillbirth of $9.97 \%$ reported by Olanite et al. (2003). The high calf mortality rate of $24.1 \%$ could be attributed to the poor management of the animals in terms of feeding, health and housing. This high mortality has a consequential impact on expansion of cattle herds and milk offtake in the smallholder dairy production. The mortality rate in this study compares with rates of $22.4 \%$ and $26.1 \%$ obtained by Otchere (1986b) and Itty et al. (1994) for traditionally-managed herds in the northern Guinea savannah area of Nigeria and Cote d'Ivoire, respectively. However, it is lower than the rate $(7.32 \%)$ obtained for cattle farmers in Ibadan, Oyo State, Nigeria (Taiwo et al., 2007). In their study of lowinput cattle production systems in tropical Africa, De Leeuw and Thorpe (1995) reported a mortality range of $5-35 \%$ for traditionally-managed calves. Analysis of the mortality rate from birth up to one

Table 2: Prevalent diseases of calf and adult cattle in the agropastoral system

\begin{tabular}{lll}
\hline Parameter & Frequency & \% of farmers \\
\hline Calves & & \\
Wet Season & 42 & 84 \\
Diarrhoea & 36 & 72 \\
Helminthosis & & \\
Dry season & 32 & 64 \\
Sand eating & & \\
Adult cattle & 22 & \\
Wet season & 30 & 64 \\
Sand eating & & \\
Diarrhoea & 45 & 90 \\
Dry season & 35 & 70 \\
Sand eating & & \\
Low milk production & &
\end{tabular}


Table 3: Calf mortality in the smallholder dairy herd

\begin{tabular}{lll}
\hline Parameter & Total no. of calves & Percentage \\
\hline Total birth & 273 & \\
Born alive & 253 & 92.7 \\
Stillbirth & 20 & 7.33 \\
Mortality in the first week of life & 45 & 73.8 \\
Mortality between one week of life and weaning & 16 & 26.2 \\
Mortality between weaning and one year of age & - & - \\
Overall mortality in a year & 61 & 24.1 \\
Seasonal mortality & & \\
Wet season & 53 & 86.9 \\
Dry season & 8 & 13.1 \\
\hline
\end{tabular}

month after weaning showed that $74 \%$ of the total mortality occurred in the first week of birth, which of course, is probably the most critical stage when young animals battle for survival. This observation is contrary to the findings in another study (Olanite et al., 2003), where mortality rate was highest between 4 and 6 months after birth. The non-occurrence of calf death during the first one month of weaning is possibly due to the adaptation of the young animals to the prevailing environmental conditions and the generally poor management. Mortality by season record showed that mortality was most prevalent in wet season; high humidity and rainfall which are known to provide conducive conditions for the proliferation of pathogenic organisms in wet season could be responsible. Parallel results were obtained by Taiwo et al. (2007), who indicated $71 \%$ mortality in wet season. Shown in Table 4 is adult cattle mortality in the study area. The adult cattle mortality, which ranged from $2.5-9.1 \%$ with a mean value of $5.8 \pm 3.96 \%$, is within the range of $2.9-14.9$ and $2.0-19.0 \%$ indicated by Otchere (1986b) and De Leeuw and Thorpe (1995) for grazing cattle in the northern Guinea savannah of Nigeria and tropical Africa, respectively. The mortality rate is, however, much lower than the rate of 24.0 $\%$ reported by Taiwo et al. (2007). The mortality rate obtained in present study seems low considering the poor management conditions the animals were subjected to. It has been reported (Ajayi and Mgbere, 2003) that the Nigerian indigenous cattle breeds offer exceptional combinations of productivity and hardiness and have a high degree of heat tolerance and ability to survive long periods of feed

Table 4: Seasonal mortality of adult cattle in the smallhold er dairy herd

\begin{tabular}{lll}
\hline Item & Total number of cattle & Percentage \\
\hline Overall mortality & 49 & 5.83 \\
Season of mortality & & \\
Wet seas on & 15 & 30.6 \\
Dry season & 34 & 69.4 \\
Mortality by sex & & \\
Females & 45 & 91.8 \\
Males & 4 & 8.16 \\
\hline
\end{tabular}


and water shortages under hostile and poor management practices. Contrary to the seasonal calves' mortality, which was predominant in dry season, the bulk of the adult cattle mortality occurred in dry season. This suggests that nutritional deficiency, a problem more pronounced in dry season, is a major cause of death or predisposing factor to infection and the adult cattle have acquired some degree of resistance to the pathogenic infection in dry season. Higher mortality among adult females compared to males could be attributed to fewer numbers of males than females in the herd. All of the male deaths were among the breeding bulls as reported by the respondents. This is possibly due to prompt disposal of the young males upon or prior to exhibition of serious symptoms of disease in order to salvage them. Besides, the females, the most needed under the smallholder dairy systems, are kept for exceptionally old age (15-20 years).

\section{Conclusion and Recommendation}

The results of this study show that the performance of cattle managed in smallholder dairy production systems in the South-West, Nigeria is poor obviously due to poor management in terms of feeding, housing and health care. Therefore, provision of supplementary feeds, better housing facilities, good health care and extension delivery systems as a means of imparting management skills and improved technologies to farmers will go a long way in improving the productivity of these animals under smallholder dairy production systems which will invariably and immensely increase milk and meat supply, and consequently improve the dwindling animal protein intake of an average Nigerian since these traditionallymanaged animals are the major sources of meat and domestic milk production.
Further research on effect of strategic feed supplementation and health interventions on the productive and reproductive performance of the animals are hereby suggested.

\section{References}

Ajayi, F.O. and Mgbere, O.O. 2003. The Nigerian cattle breeds: productivity indices and potentials for improvement. In: Taiwo, A.A., Raji, A.M., Ogbona, J.U. and Adebowale, E.A. (Eds.), Proceedings of the 28th Annual Conference of the Nigerian Society for Animal Production, pp. 147-150.

Alawa, C.B.I., Mohammed, A.K., Oni, O.O., Adeyinka, I.A., Lamidi, O.S. and Adamu, A.M. 2001. Prevalence and seasonality of common health problems in Sokoto Gudali cattle at a beef research station in the Sudan ecological zone of Nigeria. Nig. $J$. Anim. Prod. 28(2): 224-228.

Barje, P.P., Ehoche, O.W., Oyedipe, E.O., Agyemang, K., Adu, I.F., Hailu, Z. and Rekwot, I. 1995. Evaluation of peri-urban dairy production systems in Nigeria; Results of the diagnostic survey phase (Final Report), NAPRI, Ahmadu Bello University, Zaria, Nigeria.

Burke, C.R. and Roche, J.R. 2007. Effects of pasture feeding during then periparturient period on postpartum anovulation in grazed dairy cows. $J$. Dairy Sci. 90 (9): 4304-4312.

Butterworth, M.H. 1983. Seasonality of calving amongst unimproved cattle in Swaiziland. Trop. Agric. (Trinidad) 60:218-220.

De Leeuw, P.N. and Thorpe, W. 1995. Low-input cattle production systems in tropical Africa: an analysis of actual potential cow-calf productivity. ILRI, 
Nairobi, Kenya.

EImansoury, Y.H., Mahagoub, M.M.M., El Rabeea, K.A., Idris, A.O., Mohammed, I.B. and Majid, A.A. 2002. The effect of supplementation strategies on reproductive and productive performance of cows kept under different husbandry systems in Sudan. In: Development and field evaluation of animal feed supplementation packages, Animal Production and Health Section, International Atomic Energy Agency, Vienna, pp. 121-134.

Fitzpatrick, Z.A. 1993. Advances in the understanding of post partum anoestrus in Bos indicus cows. In: Strengthening research on animal reproduction and disease diagnosis in Asia through the application of immunoassay techniques, IAEATECDOC-736, pp. 19-35.

Galina, C.S. and Arthur, G.H. 1989. Review of cattle reproduction in the tropics. Part 3: Puerperium. Anim. Breeding Abstract 57: 899-910.

Itty, P.G., Rowlands, G.J., Traub, D., Hecker, P., Coulibaly, L. and D'Leteren, G. 1994. Etude economique de la production bovine villageoise dans une region du nord de la Cote 'd'Ivoire infestee par les glossines. Review Elev. Méd. Vét. Pays trop. 44 (3): 333-343.

Iyayi, E.A., Okoruwa, V.O., Babayemi, O.J. and Peters, O.F. 2003. Livestock production pattern of agropastoralists in peri-urban centres of South-West Nigeria. Nig. J. Anim. Prod. 30 (1): $87-$ 92.

Karbo, N., Bruce, J. and Okantah, S.A. 1998. A survey of peri-urban dairy in northern Ghana. Paper presented at the 1st Biennial National Agriculture Research Project Conference,
November 1998, Accra, Ghana.

Lents, C.A., White, F.J., Ciccioli, N.H., Wettemann, R.P., Spicer, L.J. and Lalman, D.L. 2008. Effects of body condition score at parturition and postpartum protein supplementation on estrous behavior and size of the dominant follicle in beef cows. J. Anim. Sci. 86: 2549-2556.

Lucy, M.C. 2003. Mechanism linking nutrition and reproduction in postpartum cows. Reprod. (Suppl.) 61: 415-427.

Mohammed, T.A. 1990. A study of periurban cattle agropastoralism in the Derived savannah of Oyo State, SouthWest, Nigeria. ILCA Humid Zone Programme Research Report, Ibadan, Nigeria, pp. 54.

Mukasa-Mugerwa, E. 1989. A review of reproductive performance of female Bos indicus (zebu) cattle. International Livestock Centre for Africa Monograph No. 6, Addis-Ababa, pp. 134.

Nasiru, A., Maigandi, S.A., Malami, B.S. a nd D a n e j i , A.I. 2009 . Characterization of cattle ownership and milk production in Zamfara Grazing Reserve in Nigeria. In: Akinlade, J.A., Olayeni, T.B., Rafiu, T.A., Akinwunmi, A.O., Aderinola, O.A., Ojebiyi, O.O. and Odunsi, A. A. (Eds.), Proceedings of the 34th Annual Conference of the Nigerian Society for Animal Production, pp. 181-183.

Nicholson, M.J. and Butterworth, M.H. 1986. A guide to condition scoring of zebu cattle. ILCA, Addis Ababa.

Okantah, S.A. 1992. Partial milk of cattle in smallholder herds on the Accra Plains: some factors affecting daily partial milk yield and milk composition. Anim. Prod. 54: 15-21.

Okantah, S.A., Oddoye, E.O.K., Obese, 
F.Y. and Mumuni, A. 1999. Effect of feed supplementation and deworming on peri-urban dairy production; in: Cattle Research Network (CARNET), IDRC/CARNET Peri-urban Dairy Project in West Africa, Ndikumana, J. (Ed.), September 1999, ILRI, Kenya, pp. 1-25.

Okoruwa, V.O., Elijah, S., Busari, A.A. and Iyayi, E.A. 1999. Production dynamics and growth rates of livestock in the Derived savannah of Oyo State, Nigeria. Trop. J. Anim. Sci. 1 (2): $187-$ 195.

Olafadehan, O.A. 2007. Potentials for improving dairy cattle production in the agropastoral farming system in the Derived savannah of Oyo State, Nigeria. $\mathrm{PhD}$ thesis, University of Ibadan, Nigeria.

Olafadehan, O.A. and Adewumi, M.K. 2007. Live weight and body condition of prepartum supplemented Bunaji cows in agropastoral farming systems in the Derived savannah of Oyo State. In: Agiang, E.A., Agwunobi, L.N. and Olawoyin, O.O. (Eds.), Proceedings of the 32nd Annual Conference of the Nigerian Society for Animal Production, March 2003, pp. 198 200.

Olafadehan, O.A. and Adewumi, M.K. 2008. Milk production and economic impact of strategic supplementation of prepartum Bunaji cows in the periurban areas of Derived savannah of south-western Nigeria. Livest. Res. Rural Dev. 20(3). Electronic version: http://www.cipav.org.co//rrd//rrd/20/3/ olaf20041.htm

Olafadehan, O.A. and Adewumi, M.K. 2009. Productive and reproductive performance of strategically supplemented free grazing prepartum Bunaji cows in the agropastoral farming system. Trop. Anim. Health Prod.41(7): 1275-1281

Olanite, J.A., Busari, A. and Akinlade, J.A. 2003. Performance of calves in the traditional Fulani agropastoral systems in the Derived savannah of Oyo State, south-western Nigeria. J. Pure and App. Sci. 6(2): 203-207.

Otchere, E.O. 1986a. The effects of supplementary feeding of traditionally managed Bunaji cows. In: Livestock systems research in Nigeria's subhumid zone. Proceedings of the 2nd ILCA/NAPRI Symposium, Von Kaufmann, R. A., Chater, S. and Blench, R. (Eds.), Kaduna, Nigeria, pp. 204-212.

Otchere, E.O. 1986b. Traditional cattle production in subhumid zone of Nigeria. In: Livestock systems research in Nigeria's sub-humid zone. Proceedings of the 2nd ILCA/NAPRI Symposium, Von Kaufmann, R. A., Chater, S. and Blench, R. (Eds.), Kaduna, Nigeria, pp. 110-140.

Pullan, N.B. 1979. Productivity of White Fulani cattle on the Jos Plateau, Nigeria 1: Herd structures and reproductive performance. Trop. Anim. Health Prod. 11:231-238.

Pullan, N.B. 1980. Productivity of White Fulani on the Jos Plateau, Nigeria: II, Nutritional factors. Trop. Anim. Health Prod.12:17-24.

Statistical Package for Social Scientists (SPSS) 11.0 for Windows. 2001. SPSS AnswerNet. Retrieved from the World $\mathrm{W}$ i d e W e b f r o m http://www.spss.com/tech/answer/

Taiwo, A.A., Fajimi, A.K., Raji, M.A., Adebowale, E.A., Ajayi, F.T. and Oke, I.O. 2007. Survey of cattle production practices in Ibadan, Nigeria. Nig. J. Anim. Prod. 34 (1): 139 
-155 .

Wagenaar, K. T., Diallo, A. and Sayers, A. R. 1986. Productivity of transhumant Fulani cattle in the inner Niger Delta of Mali; ILCA research report No. 13, Addis Ababa.
Zakari, A. Y., Molokwu, E. C. I. and Osori, D. I. K. 1981. Effect of seasons on the oestrous cycle of cows (Bos indicus) indigenous to northern Nigeria. Vet. Rec. 108: 213-215 